Al-Uqud: Journal of Islamic Economics E-ISSN 2548-3544, P-ISSN 2549-0850 Accredited No. 28/E/KPT/2019
Volume 4 Issue 1, January 2020

DOI:10.26740/al-uqud.v4n1.p83-103

Page 83-103

\title{
The Islamization of Economic Systems: A Methodological Approach
}

\author{
Denizar Abdurrahman Mi'raj ${ }^{1}$, Nissar Ahmad Yatoo ${ }^{2 *}$ \\ ${ }^{1}$ Department of Islamic Economics, Faculty of Economics and Business, Universitas \\ Airlangga. Jalan Airlangga 4, Surabaya 60286, Indonesia \\ ${ }^{2}$ Department of Islamic Economics Banking and Finance, International Open University \\ 2nd Floor, Microtech Building, 122 Kombo Sillah Drive Tallinding, The Gambia.
}

\begin{abstract}
This paper is an attempt to discuss Islamization of economics in historical perspective. Focus of the discussion is not only the Islamization of economics but also realization of an Islamic economic system. This research is based on library research methods and supported by historical analysis. Conclusive information was collected from various studies and analysed for the conception of implementing methodological steps to realize the Islamization of the economic system. Studies were reviewed and investigated in three stages: general, exploratory, and focused learning. The findings of this study reveal that Islamization of economics cannot stand alone without the Islamization of every Muslim and the Islamization of society. Like Islamization of a society is realized with organization of Muslim families, Islamization of economics can be realized by increasing the number of economists who have knowledge of sharia.
\end{abstract}

Keywords: Islamization of society; Islamization of economic system; Islamization of economics.

Paper type: Review paper

*Corresponding author: yatoosiraj@ gmail.com

Received: December 01, 2019; Accepted: January 13, 2020; Published: January 20, 2020

Cite this document: Mi'raj, D. A., \& Yatoo, N. A. (2020). The Islamization of Economic Systems: A Methodological Approach. Al Uqud: Journal of Islamic Economics, 4(1), 83103 doi: http://dx.doi.org/10.26740/al-uqud.v4n1.p83-103

Copyright (C) 2020, Al-Uqud: Journal of Islamic Economics http://journal.unesa.ac.id/index.php/jie 


\begin{abstract}
Abstrak: Makalah ini merupakan upaya untuk membahas islamisasi ekonomi dalam perspektif sejarah. Fokus diskusi bukan hanya islamisasi ekonomi tetapi juga realisasi sistem ekonomi Islam. Penelitian ini didasarkan pada metode penelitian kepustakaan dan didukung oleh analisis historis. Informasi konklusif dikumpulkan dari berbagai penelitian dan dianalisis untuk konsepsi penerapan langkah-langkah metodologis untuk mewujudkan Islamisasi sistem ekonomi. Studi ditinjau dan diselidiki dalam tiga tahap: umum, eksplorasi, dan pembelajaran terfokus. Temuan penelitian ini mengungkapkan bahwa islamisasi ekonomi tidak bisa berdiri sendiri tanpa Islamisasi setiap muslim dan Islamisasi masyarakat. Seperti Islamisasi masyarakat yang direalisasikan dengan organisasi keluarga Muslim, Islamisasi ekonomi dapat diwujudkan dengan meningkatkan jumlah ekonom yang memiliki pengetahuan syariah.
\end{abstract}

Kata kunci: islamisasi masyarakat; islamisasi sistem ekonomi; islamisasi ilmu ekonomi

\title{
INTRODUCTION
}

Everything related to the problems of life should always start with the Qur'an and the Sunnah. This should be a very common methodological pattern practised by every human being who has consciously surrendered himself to God. Similarly, at the beginning of this study, the verse: "... this day I have perfected your religion, and have given you my favours, and have made Islam a religion for you ..." contained in the letter al-Maidah verse 3 is a very interesting thing to serve as a foundation in responding to confusion of Muslims in all fields today. The Qur'anic verse emphasizes that Islam as a final religion must be accepted and fully understood. Islam is a religion that is preferred and approved by God, and He has sent the most important and respected apostle as the bearer of that revelation of His scripture (Ad-Dimasyqi, 2002). His scripture is the most authentic guide that a book can be made in managing this earth. This management task covers everything including economic activities. Thus, when the economic activities managed based on God's rule, a truly prosperous society will be created.

Historically, it can be observed that everything related to the Qur'an is a noble thing. Ramadan is a great and glorious month due to the descent of the Qur'an in that month (At-Thayyar, 2010). The angel Jibril is the leader of the angels because of his duty to convey revelation (the Qur'an) to the Prophet (Zen et al., 2014). Arab societies and civilizations, which at that time did not count in world order because of their barren and uninteresting territory, later became the most progressive and civilized societies due to the downfall of God's revelation in that society (Mahayudin et al., 1997), and the progress in economic areas marked by the closing of the Jewish market full of false transactions, replaced by the Islamic economic system (Fathurrahman, 2010).

As the most perfect religion, Islam provides limits and substantive rules that can be used as the basis for the thinking of Muslim economists today in conducting economic discourse. However, the minds of the world's intellectuals today, especially Muslims, still use the Western paradigm in building scientific philosophy. One example is the paradigm that science must be free of values. This leads to various sciences that ignore religious, moral, and ethical values. Science is built on the foundation of secularism. The process of testing knowledge must indeed 
remain objective. However, the main source of knowledge for Muslim scientists must still be derived from the Qur'an. It is because al-Qur'an can be a starting point for Muslim scientists in discovering science empirically with the instructions that have been mentioned in the Qur'an and supported by the Prophet's hadith. For this reason, the project of Islamization of knowledge began to be carried out by Muslim scientists in the last few decades.

As we know that Islamic economics is a form of success of the Islamization of knowledge. Various Muslim intellectuals explain what is meant by the Islamization of science in general. The Islamization of knowledge was an attempt to translate modern knowledge into a language that could be understood by the Muslim community where they lived (Fridiyanto, 2018). This means that the discourse of the Islamization of knowledge is more an attempt to bring together the ways of thinking and acting (epistemological and axiological) of Western and Muslim societies (Safiq, 1995).

Meanwhile, Al-Attas (1978) is of the view that the Islamization of knowledge regarding ontological and epistemological changes is related to changes in world view which is the basis for the birth of science and methodology used to conform to Islamic concepts. Simply put, throwing away the main concepts of the West, incorporating the main concepts of Islam into knowledge.

Furthermore, according to Al-Faruqi, Islamization of knowledge is an attempt to Islamize scientific disciplines or rather produce handbooks (basic books) in tertiary institutions by re-pouring modern scientific disciplines into Islamic insight after a critical study of both Islamic knowledge systems and West (Al-Faruqi, 1995). This understanding is clearer and operational than the previous understanding, besides that al-Faruqi also provides operational steps for the implementation of this knowledge Islamization program (Nurcholis, 2014), as mentioned by Zarqa (2003) about 12 steps for the Islamization of various scientific disciplines.

Based on the discourse of various Muslim scholars, the idea of the Islamization of knowledge is an effort to build a scientific paradigm based on Islamic values, both on theological, epistemological, and axiological aspects (Nurcholis, 2014). The idea has succeeded in attracting a discipline that is today known as Islamic economics. However, as the problem of the methodology of Islamic economics began to be resolved, new problems emerged which were feared to affect the development of the Islamic economy itself in terms of theoretical and implementation in the field. One of them was mentioned by Zarqa about the needs of Islamic economic human resources.

Scholars who have contributed to the Islamization of economics can be classified into three categories namely, economists, Islamic scholars, and Mukhadramun scholars who are experts in economics and sharia. The first two categories are widely available today. However, the number of scholars in the third category, which includes economists with good Islamic knowledge and Islamic scholars with good economic knowledge, is indeed still small. This is the main obstacle to Islamizing the economy (Zarqa, 2003). This third category can bring together, overcome, and coordinate problems among economists and Islamic 
scholars. Mukhadramun intellectuals will use their sharia knowledge to solve economic problems following religious guidance.

The implementation of several steps in the Al-Faruqi work plan relies heavily on the presence of economists with good shariah knowledge and shariah experts with good knowledge of economics. The number of scholars in this category is still very small. Therefore, this can be an obstacle to economic Islamization. Thus, the main discussion in this paper is to complete al-Faruqi's work plan in terms of preparing his human resources. In other words, eliminating the inhibiting factors of Islamization of the economic system as mentioned earlier. Because, all state activities; political, economic, and others are based on the role of human resources as initial capital (Syamsuri et al., 2019).

In practice, sometimes the attempts to Islamize the economic system clash with the modern capitalist economic system that has become ingrained in society. For example, religious rules that guide the profit-loss sharing scheme (PLS) of Islamic financial institutions in practice clash with the characteristics of a modern capitalist ethos that uses interest with an ethic of risk elimination. It is because the interest system will ignore the loss or profit obtained by business managers. This is very different from the rules of al-ghunmu bil ghurmi in Islam (the risk will always accompany return expectations). PLS schemes that are not applied by Islamic financial institutions just because they do not want to lose, will make Islamic finance artificial. Therefore, Islamic financial institutions involve themselves in pseudo-spiritual finance by selectively re-contextualizing Islamic financial schemes and adjusting the substance of religious prescriptions (Hidayah et al., 2019). This is then considered by ordinary people that the implementation of the Shari'a in the Islamic economic and financial system today is too liberal and only presenting a pseudo-Islamic economic system. Islamic financial institutions try to refocus the emphasis on PLS contracts into contracts that are commodified such as tawarruq (monetization/sale and repurchase transactions), bay 'bi thaman ajil (sale by instalment contract), bay' al-'inah (sale by repurchase immediate / sale by repurchase transaction), or bay 'ad-dayn (debt certificate sales) (Hidayah et al., 2019). The impact is that the data from the IFSB Stability Report (2016) shows a downward trend in the market share of PLS products since 2008. Whereas the PLS principle that is more prevalent in mudharabah and musharaka contracts teaches the values that in a profit and loss situation it must be enjoyed together, may not feel pleasure alone above the suffering of others (Hanifullah, 2012). This is a manifestation of human relationship in economic activity.

Islamic economic activities in Indonesia develop very slowly. This is reflected in the market share of Islamic banking which from 2014 to 2018 only rose by $0.2 \%$. In 2014 , the sharia banking market share was $5.5 \%$ (Dwiantika et al., 2014) and in 2018 the sharia banking market share was 5.7\% (Septyaningsih et al., 2018). All problems caused the slow economic system of Islam which effectively implemented rooted in the weak spirituality of human resources or the Islamic community itself. Dariah et al stated "... the new approach to the achievements of SDGs in Muslim countries requires spiritual" injection "and a shift in the system that regulates development which leads to an Islamic economic system, Islamic social system, and Islamic government system ..." (Dariah et al., 2016). This shows 
how important is the development of human resources who are ready to participate in efforts to Islamize the world economic system today. The very small market share of Islamic banking in Indonesia means that the conventional economic system that uses the usury practice still controls and covers most of the economic activities today.

The ironic fact about this small market share is the practice of the Islamic economic system related to banking and finance, which is only in the form of Islamic banking and financial machinery system. Moral hazard practices in Islamic banking and finance and banking still occur, desipite the Shari'a contract is used in transactions. Although the practices of Islamic baking and finance are sourced from the foundation of monotheism but the implementers of the same are not yet solid. The solidity of the foundation of monotheism will lead people to the side of humanism that has more integrity. Humans who feel themselves are always watched by their Lord, will not dare to do moral hazard.

Until nowadays, the discourse on the Islamization of science, in this case, the economy, still gets comments from the scientific methodological side. As an article written by Mohd Mahyudi and Enizahura Abdul Aziz published in July 2018 in the Journal of King Abdulaziz University: Islamic Economics in response to the issues discussed by Volker Nienhaus in his 2013 article entitled "Method and Substance of Islamic Economics: Moving Where? "also published by the Journal of King Abdulaziz University: Islamic Economics (Nienhaus, 2013). Mahyudi and Abdul Aziz want to clarify some basic things about the substance and methods of Islamic economics through several points of agreement and disagreement with Nienhaus, by paying attention to a large number of academic works that have been published in the last five years (Mahyudi et al., 2018). The long period of discussing the discourse on science causes the lack of attention of Muslim economists to even more substantive matters. Some Muslim economists do need to respond to work that is considered to be misleading to society at large. However, there must be others who focus on fixing the substantive matter which will have more impact on the discourse of the Islamization of economics and the economic system itself. An article in the same journal publisher briefly discussed about Islamic Economic research that carried out at a theoretical and empirical level. However, the researches presented are still revolving around the academic development of Islamic economics and the development of an applied Islamic economic system that can be carried out. For example, in the early days of Islam, the main focus of economic knowledge was on simple production relations, exchanges with little demand for government security and justice, which meant there was little room for modern academic discourse (Tahir, 2017). Furthermore, in the fourteenth century, Ibn Khaldun (1332-1406 AD) uses a writing style that close to the style of modern economics (Boulakia, 1971) (Tahir, 2017). However, there are no Muslim economists or Muslim scholars who discuss how to produce economists like Ibn Khaldun so that the Islamic economy can truly be grounded and integrated with people's lives.

Another researcher, Basharat Hossain tried to find out the successes and problems of the process of Islamization of monetary policy among twenty-seven (27) OIC member countries in Asia and provide future direction to improve the 
Islamization process. Basharat Hossain found more than one hundred and fifty-four (154) Islamic commercial banks operating under a conventional monetary policy in twenty-three (23) countries with very few Islamic monetary tools (Hossain, 2019). Then, based on his research, Hossein recommended six steps to accelerate the Islamization process. One of the recommendations related to developing human resources is the provision of Islamic economic scholarships to nurture Islamic economic expertise. Hossein said that a scholarship was at least a hundred times stronger than the holding of an expensive conference (Hossain, 2019). This means that preparing human resources is more important than just creating a system.

An interesting thing that mentioned by Mahyudi in his research is widely the huge gap existed in the form of not achieving social goals, has directed research to identify serious errors in the micro-foundational aspects of Islamic economics; which have not been considered before (Mahyudi, 2016). Thus, a more holistic reading of the Qur'an can solve this micro-foundation problem, which in the next stage will lead to the Islamization of a more advanced economic system (kaffah).

Based on this background, this paper is an attempt to discuss and arrange the Islamization of the economic system based on a more comprehensive perspective. Precisely, researchers want to devise methodological steps towards achieving an Islamic economic system. This is intended to not only seek Islamized economic system but to realize a system supported by God-conscious human resources and their duties as caliphs on earth.

\section{RESEARCH METHODS}

This research is based on library research and has used descriptive analysis techniques supported by historical analysis. As it is known that one-third of the contents of the Qur'an are to explain the story or history. This enables humans to take lessons from history. All research on this earth must have a background history of why it must be examined. The historical approach prioritizes the orientation of understanding or interpretation of historical facts. In this case, history acts as a method of analysis (Multazam, 2013). Besides, the fact that history repeats itself, even with different figures, different situations and conditions, and the complexity of different problems, but the substance remains the same (Browne, 1977). History can be repeated, if the conditioning and substantive treatment are carried out appropriately and based on what has happened during the historical period (Browne, 1977). The Islamization of the economic system took place at the time of the Prophet Muhammad shallallahu 'alaihi wassalam. The concepts and methodological steps in the Islamization of the economic system that implemented by the Prophet and his companions can be repeated in the present in a condition that adjustments made to the complexity of the current system and in a more substantive way than what has been implemented at this time.

The stages of data collection start from the most authentic sources, namely the Qur'an and the hadith which become explanatory to a problem and how the Shari'a guidelines solve the problem. Then, secondary data is in the form of literature on the development of the Islamization of science in general and in particular the field of economics and its impact on the Islamization of the economic system. Some conclusive information was also collected from the results of studies 
and seminar results related to the interpretation of the Qur'an and the more operational Hadith as supporting data for the conception of implementing methodological steps to realize the Islamization of the economic system.

This research applies descriptive analysis method to analyze data. Data is reviewed and investigated in three stages; general, exploratory, and focused learning. This is a comprehensive material to summarize the findings and conclude the results. Historical analysis is done by collecting, exploring, and focusing on studying the substance of Islamic historical data related to the process of Islamization of the economic system that occurred at that time with the guidance of the Qur'an and the Hadith. Furthermore, the formulation and preparation of methodological steps can be carried out now based on historical substances that have been collected previously.

\section{RESULTS AND DISCUSSION}

\section{Al-Faruqi's Work Plan for the Islamization of Knowledge}

Al-Faruqi's concern over the condition of Muslims who were immersed in the adoption of the western education system led him to conclude that there was no other way to revive Islam and help the misery of the world, except by reexamining the cultures of Islamic past and present western culture (Sardar, 1998). Dr AlFaruqi initiated a work plan for the Islamization of various scientific disciplines consisting of 12 steps (Al-Faruqi, 1995). The twelve work steps have three important points; (1) the Muslim's obligation to master the classical treasures, (2) examine the Western treasures by critically examining them through the perspective of the Qur'an, and (3) accommodate the two treasures into a creative synthesis to display a form of Islamic teaching discipline that is intact, integrated, and not dichotomous, under the emanation of monotheistic values (Baharun, 2016). Zarqa mentioned that al-Faruqi's plan consisted of 12 steps that could be applied to any discipline (Zarqa, 2003). Collectively, these steps are a comprehensive map by which one can plan the progress achieved in Islamizing a particular discipline. The steps are as follows:

1) Prepare a diagram of the contents and methodology of a related discipline.

2) Conduct a comprehensive review of the development of the relevant discipline and its main assumptions.

3) Prepare readings picked from the Islamic heritage in the related subject of the discipline.

4) The book reading should be classified according to the main division of discipline.

5) Analyze previous readings and determine their relationship with discipline.

6) Determine in detail the Islamic assumptions related to the discipline.

7) Evaluate the contribution of Muslims to discipline for centuries.

8) Present the main problems facing the Muslim nation related to discipline.

9) Presents the main human problem.

10) Reformulate the discipline from an Islamic perspective in such a way as to realize the interrelation and integration between the 
assumptions of Islam and the contribution of Islamic heritage on the one hand, and the best achievements of the current discipline.

11) Preparing a textbook about the disciplines at the university level.

12) Disseminate the contents of disciplines among specialist on a huge scale.

As previously stated, technically, the output of al-Faruqi's work plan was to produce handbooks in college. For the sake of justifying economic science, this is already very comprehensive. However, what is at stake is what kind of education can bring about the realization of economic Islamization to minimize possible obstacles. If it were only for teaching in college, then it would be very unlikely that it would be easy to forge a human resource that fully understood Islamic law and economics. Especially educating on years for undergraduate age is the foundation of inhumanity to be taught at an early age. As Ibn Katsirdalam says Q.S. An-Nasr verses 1-3, "Therefore most call upon God and His Messenger are young men. As for the people of the Quraish community, most of them maintained their paganism, no one converted to Islam except for a few " (Ad-Dimasyqi, 2002). Not to mention the number of Muslims who have had the opportunity to pursue their education at the college level. Therefore, if the standard and educational pattern remain in the Western pattern, Islam will still be difficult to absorb in Muslim life, let alone the economic Islamization.

Al-Faruqi's main work such as Islamization of Knowledge: General Principles and Work Plans and Islamization of Knowledge: Problems, Principles, and Prospective has given birth to a holistic perspective of education and developed its ethical concepts based on the principle of monotheism and worldview (Rahman et al., 2015). Al-Faruqi tried to develop progressive ideas and frameworks of education that advocated monotheistic values and ideas derived from divine inspiration and reason and rational and scientific views (Rahman et al., 2015). Although the thought of the Islamization of knowledge has been criticized by several other Muslim intellectuals such as Ziauddin Sardar who put forward the idea of Islamic science, and also Fazlur Rahman (Taufik et al., 2017), but both ideas that equally lead to the improvement of education become the most important point for the creation of Islamization of knowledge itself. Furthermore, the improvement of education aims to restore the glory of Islamic civilization that had happened a few centuries ago.

This paper does not attempt to replace Al-Faruqi's work plan as the purpose of the research is very different. Al-Faruqi's work plan is correct if it is based on his thinking set and following the goals he set. Therefore, the rebuilding of the work plan or steps in this paper aims to further and further Islamize Islamic economics. It is even possible that this work plan will be combined with the work plan for Islamization of al-Faruqi's knowledge to support the Islamization of an economic system. Therefore, to formulate methodological steps towards the Islamization of an economic system, various sources of Islamic legal literature and holistic historical studies are needed. For specific, regarding education, the estuary of the Islamization of knowledge lies in the concept of education that will be implemented. The main reason this paper uses the historical approach is that with 
the history we can find various events and problems that have solutions. In simple terms, concepts that have been tested by history can be duplicated and adapted to contemporary issues. It includes the concept of how Islamic education in classical times could produce Muslim scholars whose expertise was not secular so that the Islamization of the economic system could be achieved.

The improvement of education that will be carried out needs to reflect on the history of how the Prophet and his companions managed aspects of education in building a civil society and Islamizing the economy which was then controlled by Jews. The embodiment of economic mastery at that time can be seen during the early days of the Prophet along with his friends migrating from Mecca to Medina. The owners of most of the markets in Medina at that time were Jews. Even the huge market of Medina at that time belonged to the Jews of the Bani Qoinuqo. This economic practice in the market was full of fraud, reducing the scales, usury, gharar, and various things that are forbidden in Islam. Therefore, the improvement of education carried out today must be based on a concept that had previously been successfully carried out by the Prophet and his companions in turning things around. At first, the Madinah economy was controlled by the Jews with its usury practices. Then, it was taken over by the Prophet and his companions to improve the economic system and to create justice and prosperity for the entire population of Medina at that time.

The process of improving Medina's economy did not take place immediately, but it required a fairly long process and had begun since the training of the companions by the Prophet in Mecca. The process of preparing for economic improvement in Medina begins with the process of improving human resources that have been going on in Mecca for thirteen years. The education of human resources carried out by the Prophet Muhammad while in Mecca was under the guidance of the revelations from Allah subhanahu wa ta'alaa. Then, it needs to be examined first, how Islamic education in the classical period formed a solid human resource and can deliver on the economic structure of civil society that is free from the practice of interest (usury).

\section{Islamic Education for Developing Human Resources in the Islamic Economy}

The wrong assumption of homo Islamicus inadvertently led to the formulation of the wrong theory (Mahyudi, 2016). This requires an immediate improvement by making a new reading of the Qur'anic text about operative economic agents (Mahyudi, 2016). This operative economic agent is a human resource that has character, thought, and character that in line with the Qur'an. In previous research, Mahyudi tried to check the reality which revealed that the weak social performance of Islamic economic institutions came from the absence of homo Islamicus (Mahyudi, 2015). The interesting part from his findings is that these weaknesses are because they are neither homo Islamicus nor homo economicus. Therefore, Mahyudi then proposed the concept of 'True-Man' as an economic agent in the Islamic economy (Mahyudi, 2015). In this connection, the fundamental improvement of economic agents can only be done through Islamic education.

Human resources as inputs of the production function together with capital demonstrate the importance of this aspect as an economic agent on the micro- 
foundation. A study conducted the relationship between education and economic growth states that higher education has the highest impact on economic growth compared to primary and secondary education (Hanif et al., 2016). Then, a study conducted by Sylvie Kobzev Kotásková et al., about the effect of education on economic growth in India with years of observation from 1975 to 2016 shows that there is strong evidence that proves a positive relationship between education levels and economic growth in India that can influence government action and shape the future of India (Kotásková et al., 2018). More specifically and substantively, Risti Permani's research on economics in Islamic education began in his conclusion that religious education has positive potential (Permani, 2009) where modern religious education is associated with pro-democracy attitudes (Asadullah et al., 2010). Religious education can also improve one's religiosity which in turn can increase life satisfaction, moral attitudes, etc. (Scheepers et al., 2002) (Greene et al., 2004).

Improvement of education becomes important in efforts to determine methodological steps towards the Islamization of the economic system. Therefore, the essence of education must be understood in-depth and thoroughly. Dangor explains clearly that the goals and objectives of education are intended to produce true and God-conscious individuals who are following the Divine mandate (Dangor, 2005). It is because knowledgeable individuals are not necessarily educated. The term 'ilm (literally means ' knowledge') covers all aspects of life that are intellectual, material, and spiritual. A holistic approach to education from this perspective means the cultivation of the mind, inner self-development and acquisition of intellectual and spiritual virtues (Dangor, 2005).

Education in Islam is not limited to serving students' material needs or providing them with professional skills and career opportunities. Education cannot be utilitarian; he cannot have career planning as his basic methodology. Knowledge is not only regarded as an end in itself by positioning it as a means to satisfy intellectual curiosity but also as a means to achieve higher moral and spiritual goals than before gaining that knowledge. For example, knowledge might encourage the development of righteous beings and affect the spiritual, moral and physical wellbeing of families, communities, and humanity in general (Dangor, 2005).

The mindset of education as explained by Dangor must be the basis of thought for every Muslim, not just for educators or lecturers of Islamic economics. Education, including the process of Islamization of knowledge and Islamization of the economic system, is not only considered as an end in itself, or a way to satisfy intellectual curiosity. Moreover, such discourse is only used by Muslim scholars to personally want to be worldwide recognized and to be known as an expert in Islamic economics. Therefore, the mindset and intention must be completely straightened out.

Education in the classical period is very interesting to study, because of its success in emerging Muslim intellectuals, such as Islamic Shari'ah, socio-economic experts and natural science experts such as Ibn Khaldun with his work Muqadimmah. In this section, researchers want to introduce Kuttab. An education role model in the classical period can be replicated into a series of methodological steps in the Islamization of the economic system. The term kuttab was known by the Arabs before Islam that aims to provide education for children. However, this 
institution did not develop and receive much attention from the Arabs. In kuttab language comes from the root of the word taktib which means teaching writing. While katib or kuttab means the writer, Kuttab is an institution where children learn to write (Fauzi, 2012).

In the early days of Islam, educational institutions consisted of two levels, the first level or basic namely kuttab / maktab and mosque which provide a lower level of education, where children knew the basics of reading, writing and counting. Another understanding was mentioned by Dahlan who explained Kuttab or Maktab words were taken from the word Taktib which means teaching writing. In another reference, Kuttab / Maktab derived from the same basic word, namely kataba which means 'to write'. Meanwhile, kuttab / maktab means 'the place of writing' or 'the place where the activities of writing are held' (Dahlan, 2018). Then, the advance level facilitates the students who want to continue their studies outside the area and expertise in their respective fields. The teaching takes place in the mosques or the house of the ulama (Yatim, 2011). At that time, the Islamic community was very eager to seek knowledge and motivate parents to take their children to learn in the mosque as a place of secondary education after Kuttab (Dahlan, 2018).

The kuttab curriculum focuses on learning the Qur'an as the main reading followed by writing. During a visit to Damascus, Ibn Jubayr saw that the writing exercises conducted by students did not originate from the Qur'anic sentences but from ordinary poems to avoid writing mistakes made by children in the learning process. Also, students receive teaching on Arabic grammar, the stories of the Prophets especially the hadith of the Prophet Muhammad, and the basics of counting, reading and writing (Hitti, 2001). However, among all curricula, memorization is the most emphasized ability in kuttab (Hitti, 1974).

Education has been a major concern since the early days of Islam. The Prophet taught the principles of Islam directly to the Muslims by reciting the Quranic verses revealed to him (Lapidus, 2000). The place of learning used by the prophet at that time was the home of al-Arqam ibn Abi Arqam and the kuttab. Because only a few people could read at that time, the Prophet Muhammad SAW ordering the people of the duchy to teach the Qur'anic reading in Makkah. It was the home of Prophet's companions who served as a place of education before emigration which flourished in early Islamic times (Dahlan, 2018).

After migration to Medina, the place of study for Muslims is a mosque, suffah, and kuttab (Fauzi, 2012). The mosque was not only a place for prayer, but also a place for Muslims to accept the teachings of Islam and the instructions of the Messenger, the centre of all activities, information centres, and discussion forums (Al-Mubarakfuri, 2016). Whereas, suffah is the porch of the mosque, the space connected to the mosque as a place to teach and learn that conducted systematically. Suffah also served as a hostel for friends who did not have a home. Those who live in this suffah are called ahlus-suffah (Antonio, 2009).

Two kinds of kuttab developed in Medina. Syalabi explained that the two kinds of kuttab, the first, kuttab which functions to teach reading and writing based on Arabic poetry texts with mostly the non-Muslim as instructors (Syalabi, 1973). Secondly, the kuttab functioned as a place for teaching the Qur'an (Syalabi, 1973). This Kuttab model not only teaches reading and writing but also memorizing the 
Qur'an al-Qur'an and the fundamentals of Islam. Other sources also stated that in the early days of Islam, kuttab has two formats. First, kuttab as a place to read and write education where the al Qur'an at this time has not been used as a reference subject to maintain its sanctity and to not cause the impression that the al- Qur'an was played by students by writing and delete it. The second format, kuttab serves as a place of education that teaches the al-Qur'an and religious foundations. In this second format, the implementation of education is more focused on religious education and character but has not reached the literacy material yet (Asari, 2013).

Rasulullah shalallahu alayhi wassalam, prepared his companions for thirteen years in Mecca with this method, before they finally being able to take over the Jewish economic empire in Medina. The preparation period is quite long but able to emerged Muslim scientists who have a strong independence character and experts in various fields of science. (Al-Mubarakfuri, 2016). This is because when the foundation of the faith and morals of the friends is not solid, the economic system of Medina will still be controlled by the Jews. Hence, preparing the human resources who become the drivers of the economy is the most priority thing to do before establishing the Islamic economic system.

\section{The Role and Strategic Function of the Family in Supporting the Islamization of the Economic System}

Islamization of economics needs to be accompanied by the Islamization of society. The most effective Islamization of society is started from the smallest organization making up this life, namely the family. Nurhayati and Syahrizal explained that the development of faithful and pious human development must start early in the family because the education that was first received by children was in their own family (Nurhayati et al., 2015). Both parents become the main foundation in the character education and character of a child. If education in the family environment is good, good economists might be born. Conversely, if education in the family environment is not good then economists might not be born. Although there are environmental factors that can be other determining factors as well, but this is in line with the words of the Prophet Bukhari, Abu Dawud, and Ahmad, which means: "Every child is born in a state of nature, it is the parents who make the child Jewish, Christianity, or Majusi. " (Al-Bukhari, 2011) (Al-Sijistani, 2013) (Hanbal, 1995).

Every human being is born in a holy state, clean and pure from all kinds of evil. Therefore, parents must provide a positive education to the child from an early age to maintain and develop the child's existing personality. This positive teaching can begin with the education of faith (monotheism). This is in line with the Prophet's command in the hadith narrated from Ibn Abbas, where the Prophet shalallahu 'alaihi wassalam said: "Teach your children at the beginning of the speech to say what is laa ilaaha illallah and teach it so that at the end of their life they will say what is laa ilaaha illallah." (Nurhayati et al., 2015).

Moreover, in the al-Qur'an Surah Luqman, Allah swt shows education stages to the successor generation. Hariyanto wrote a series of lectures and educational patterns based on Q.S. Luqman described by the infidels (mufassirs are those who interpret the Qur'an and the Hadith) within the scope of Madrasah al-'Ula (Hariyanto, 2016),: 
1) There is one thing that every parent should 'do' before engaging in educational activities for their children: "Educate yourself, by improving your character (preparing yourself as a parent who will be an educator). The bottom line is Q.S. Luqman verse 12.

2) To maintain a child-centred family education, which is primarily implemented in the form of "guardians" (advice). The bottom line is Q.S. Luqman verse 13.

3) Perform the construction of beliefs through the process of transformation of values and cultures (ta'dib) as mentioned in Q.S. Luqman verses 14-15.

4) Perform the social development of the child, primarily through the processes of ta'lim and tabiyyah (the transformation of science and behaviour). The foundation is Q.S. Luqman verses 16-17.

Thus, this concept can be used by Muslim economists to carry out the process of Islamization of society which will ultimately lead to the Islamization of the economic system. Every human being as homo economicus and homo islamicus must be equipped with family knowledge, and understand in-depth how the essence of education should be in the view of Islam before engaging in society and economics. It is because only from the family, the foundation of ethical and moral are established. Low morals will be very dangerous for social life and can destroy the foundation of economic, national and state activities (Wangsadanureja, 2018).

In a family, a father has an important role to play as an educator for his family. A father has as much responsibility as a school principal in family education. His responsibility is arranging religious affairs in his family to keep himself and his family safe from the threat of hellfire in the hereafter (Wangsadanureja, 2018). As stated in the Qur'an Letter at-Tahrim verse 6, "protect yourself and your family from the fire of hell whose fuel is man and stone; the guardians of the angels are harsh, hard, and disobedient to Allah for what He has commanded them and always do what He commands" (Al-Qur'an, 2015). Therefore, the foundation of human character as a homo-economicus and a God-conscious Islamicus would be very important at this stage.

Meanwhile, the role of mothers, as the ulama stated ': al-ummu al-madrasatul 'ula, mothers are the first madrasa for children (Nurhayati et al., 2015). Since in the womb, a mother has educated her child. The process of human resource education, in this case, a potential driver of the economy, cannot be easily overlooked by Muslim economists who actively discussing the Islamization of economics. This is because Islamic economics is inseparable from the application of basic values of morality and virtues that lead the Islamic economic system implemented in a kaffah way. A mother is very instrumental in laying and planting these basic values in every human being who will later become the driving force of the Islamic economy. Like it or not, this stage must be included in a series of work plans for the Islamization of the economic system. If it is then considered that this discourse goes too far beyond the limits of the economic scientific box, then it is too naive if Muslim scholars today only contemplate with an open mind and limit very integrative knowledge. Even the science of Islamic economics is inseparable from ethics and values, which is not in the Western epistemology. It is these values which 
should animate the economic behaviour in an economic system that is commonly known to us by its universal nature (Nurcholis, 2014).

Accordingly, the task of educating this Muslim generation should be wellstudied by every mother and prospective mother. History records how the women of the Prophet's day learned and questioned the various problems they faced, without being overwhelmed by shame. This shows their high awareness of science, as stated by 'Aisha r.a. and narrated by Muslims, Abu Daud and Ibn Majah which means, "The best women are Anshor women. Shame does not deter them for tafaqquh (deepening their understanding) about religion" (Hajaj, 2008) (AlSijistani, 2013) (Ibnu Majah, 2018). A mother does have more teaching hours than father. Therefore, a mother should be more diligent in her learning religious knowledge and deliver it to her children (Wangsadanureja, 2018).

The revitalization of a family's strategic function as the smallest organization that forms civilization has become important in efforts to Islamize the economic system. In a system, there are variously integrated devices so that the system can run well and correctly. Even in Islam, the most important tool for running a system is the human resources that manage the system. Similar to the Islamic economic system, the most important thing is the human resource who run the Islamic economic system. That is why Rasulullah shalallahu 'alayhi wassalam nurtured Islamic human resources first by educating his companions for thirteen years in Mecca, and only afterwards, he created the economic system and order of the civil society in Medina for ten years.

\section{Methodological Steps to the Islamization of the Economic System}

It is necessary to know that the Islamization of economics and the Islamization of the economic system are two different things. The Islamization of economics is the effort to Islamize knowledge, which means building a scientific paradigm based on Islamic values, both on the aspects of ontology, epistemology and axiology. So, what is important to do in giving birth to an Islamic economy is to explore the guidance of the Qur'an based on the framework of the three (Nurcholis, 2014). Meanwhile, the Islamization of the economic system is the effort of Islamization in economic life. The concentration is more on implementation or practice and more tangent to the aspect of axiology. In essence, these two things are interrelated and one influences the other. Therefore, before determining the steps of the work plan, it is necessary to strengthen the objectives of Islamization itself. Al-Faruqi specifically mentions the objectives of the Islamization of knowledge as follows (Al-Faruqi, 1995):

1) Mastery of modern scientific disciplines

2) Mastery of treasures of Islamic heritage

3) Building the relevance of Islam to each modern scientific discipline.

4) Integrate values and treasures of Islamic heritage creatively with modern sciences

5) Deliver Islamic thought on the paths that only intended to gain fulfilment of God's plan pattern.

The aim of the Islamization of knowledge should be more comprehensive. As mentioned before, science is not the final destination. Mastering many things but 
not being able to fuse with the reality of life, is a futile thing. Science is a means to do da'wah and charity. Because of good deeds and great da'wah by Rasulullah shalallahu 'alayhi wassalam, the realization of justice in social life, human happiness, both in the world and in the hereafter will be achieved (Al-Mubarakfuri, 2016). Therefore, there is a need for mutual understanding among Muslim economists to not only be trapped in the romanticism of science alone, as science without charity is like a tree without fruit.

In addition to charity, morality is also fundamental. As Umar bin Khattabradhiyallahu 'anhu says, "manners are first before knowledge". Imam Ibn al-Mubarak also says, "I have learned manners for thirty years, and I have learned for twenty years" (Hanafi, 2017). This Prophet's companion and salafus-salih statement indicate the importance of manners before knowledge.

There are three main steps that Muslims must take to achieve the Islamization of an economic system. Dr Abdul Majid al-Ghaili who studied the Qur'an based on the order of his letter, in his book Muqaddimah in the book of Kaifa Yubarmiju alQur'anu al-Hayaah, he explained three major sections of the Qur'an based on its descent (Ali, 2014). The first third of al-Qur'an verses focus on the formation and refinement of the individual, Muslim personalities. The second third of it, regulate and improve society. Then, the last third of it was to regulate the affairs of the nation and to improve the system of economy and government.

The Qur'an has many instructions and lessons that can be taken to solve all the problems of economic life. Including the descending order of verses of the Qur'an can be the basis of a strategy or concept in the Islamization of an economy and the Islamization of civilization afterwards. The uncivilized Arab society was gradually formed into a just and civilized society by Allah through His Messenger with the guidance of al- Qur'an. Hence, the three major stages that need to be followed by Muslim economists today are: First, they must complete with themselves; Second, creating about social rules, and third, the formation of the system will be achieved if the community is ready to run the system. All three stages are inseparable from the process of Islamic education through the family in forming a private Muslim economist who readies to carry out Islamic economic values.

The Islamization of economics must be directed towards the Islamization of an economic system. Thus, it is not finished by just Islamizing science. Because the Islamization of economics cannot stand alone without the self-Islamization of every Muslim (not enough with Islamic religious information printed on the citizen identity card / KTP) and the Islamization of society first. Furthermore, the appropriate methodological steps to realize the Islamization of the economic system can be formulated as follows:

1. Self-Islamization of every Muslim through the role and function of the family. The stages of self-Islamization of every Muslim must begin with early education, which is to revive the strategic role and function of the family to form humans who are not only homo economicus but also homo Islamicus. Based on the literature excavations conducted by researchers, to this day there has not been an educational institution that involves the full role of parents in the family to be involved in the education of students, except for one namely Kuttab al-Fatih. This educational institution applies a classical Islamic education system. 
Kuttab Al-Fatih is a basic level educational institution for children from the age of 5-12 years with a period of education for seven years with a concentration on two main curricula, namely the Faith curriculum and the Al-Qur'an curriculum (Al-Fatih, 2017). This curriculum does not refer to the national education curriculum, because the operational permit is also a permit for the non-formal implementation of the PKBM (Teaching and Learning Activities Center). The general subjects taught are subjects that refer to the National Joint School Final Examination (UASBN). The virtues that arise in students not only from the role of the teacher, but there is the role of parents/guardians of students. Parents will be invited to work together to improve mutual patterns and learning climate at home. The Kuttab also held a meeting with the guardians of the students called the parents' school (Novianti, 2015). The percentage of learning as much as $30 \%$ of learning material at school and $70 \%$ of the material provided by parents at home.

Kuttab Al-Fatih believes that their concept is not a new educational concept, because it is already mentioned and implemented in historical records. Nevertheless, its historical records have long been buried. Therefore, the institution is trying to delve its history so that it can be implemented for generations in this era and emerging a generation of scientists who are also ulama'.

The existence of the Al-Fatih kuttab educational institution seems to be an answer to the challenges and obstacles of Islamization of knowledge mentioned by Zarqa. The classical education system has succeeded in bringing Islam to the pinnacle of glory and gold for centuries (Novianti, 2015). Especially in the Abbasid Daula, Islam became a superpower and became the centre of the scientific world. Many knowledge seekers and scholars come to visit both to teach and to learn from scientists. This can be duplicated and modified without departing from the instructions of the Shari'a and history so that the task of expanding the number of resources of economists who have good economic and sharia knowledge can be carried out on a massive scale. This will certainly lead to the Islamization of the economic system in kaffah way for long periods.

\section{Islamization of society}

The self-Islamization of every Muslim will have a snowball effect on the Islamization of society. Each Muslim family will begin to understand the Shari'a in economics. As a result, economic rules in society will be held indirectly. Over time, there will be more human resources who has the ability and expertise of economics as well as sharia, called Mukhadramun.

If the number of Mukhadramun becomes the majority, it is enough to be able to influence the environment and surrounding communities to carry out economic activities based on Islamic law. Besides, this mukhadramun can also influence the community through Friday prayer platforms. Therefore, the discussion on Friday prayer is not only focused on the discussion about being pious in the afterlife dimension but also the discussion about how to become a pious human being in the world dimension that might affect the afterlife itself such as the discussion about Islamic economics. 


\section{Islamization of state systems and procedures}

Furthermore, Mukhadramun needs to work on important government posts, which in turn leads the country to Islamization of the state system and order. Included in this is the process of Islamization of an economic system. Mukhadramun is not represented as a cleric or an ustadz who is considered incompetent in the economy and in managing the country affairs. On the contrary, this mukhadramun is a professional economist who merged into a society whose shariah expertise is an antidote to a community environment that has been engulfed in a turbulent economic cycle.

Mukhadramun, who occupies an important position in the government, will try to actualize the Qur'anic orders to resolve the socio-economic realities that occur in the country. For example, they will object to the usury system. The Qur'an substantially mentions in surah al-Baqarah verses 275 -276 about how usury is directly confronted with the sale and purchase (bay ') in verse 275 and how alms instruments are used against usury in verse 276. Thus, a Mukhadramun will use Qur'ani's instructions as a strategy to improve the system and state administration, especially in the economic. In the era of Rasulullah (SAW) and his companions, usury was defeated by sharia trading and fertilizing alms as a socio-economic safety net. Buying and selling (bay ') as an illustration of the real sector in the economy, will be a pressure point in making the country's economic policy. Furthermore, there are also many discourses on Islamic Social Funds or Islamic Social Finance which become the manifestation of various types of alms based on the Qur'anic guidance to build an economy against the usury system.

The Islamization of economics must go along with a series of methodological steps to realize the Islamic economic system. At this stage, even without calling it an Islamic economic system, an economic system driven by muhkadramun will become Islamic naturally. It is because Islam is a solution to all problems of life, including economic problems. Islamic economics has relevance for not only Muslims but also all humanity who are interested in a durable solution to the problems of the financial crisis, inflation, unemployment, poverty, and economic inequality (Tahir, 2017). In the long run, the idea of realizing civil society becomes a necessity if countries that want to implement a unified Islamic economy. The failure of various economic systems that caused a crisis has become a lesson for humans to repeat the same mistakes. With the Islamic economic system, human economic civilization will be able to become better.

\section{CONCLUSION}

The Islamization of economics must go hand in hand with the implementation of appropriate methodological steps in realizing the Islamization of the economic system. Based on an analysis of the history of Islamic civilization in the time of the Prophet and his companions, the formulation of these methodological steps included: First, the self-Islamization of every Muslim as a form of preparing human resources that drive the economy. This needs the awareness of every Muslim family in a country. Second, the Islamization of society creates snowball-effect if the majority of Muslim families in a country can prepare human resources of the Mukhadramun type. The Islamization of this society began with the smallest 
organization of society, namely every Muslim family to carry out the process of self-Islamization of every human being born into a family. Increasing the number of economists who have good economic knowledge and Islamic law must begin with education at the family level so that the Islamization of the economy is not hampered. As said by scholars that the first madrasa of civilization is in the family. Therefore, an improvement in education is needed starting from the family environment followed by curriculum improvements in educational institutions that currently exist. As a result, Islamization of the economic system can be realized in a kaffah way. Third, the Islamization of the state and economic system in which the goal of the Islamization of the economic system itself merges with this third methodological step.

More experimental research is needed as the prospective future research to follow-up to this study. Research should empirically prove how these methodological steps are able to Islamize an economy and repeat the success story of Islamic economy which replaced the usury-based Jewish economy in the past.

\section{REFERENCES}

Ad-Dimasyqi, A. I. A. (2002). Ter. Tafsir Ibnu Katsir Juz 6. Bandung: Sinar Baru al-Gensindo.

Al-Attas, N. (1978). Islam and Secularism. Dalam A. Soleh, Wacana Baru Filsafat Islam (hal. 240). Yogyakarta: Pustaka Pelajar.

Al-Bukhari, A. (2011). Ensiklopedia Hadits: Shahih al-Bukhari 1, Terj. Masyhar dan Muhammad Suhadi, Cet 1. Jakarta: Almahira.

Al-Faruqi, I. R. (1995). Islamisasi Pengetahuan (terj.). (A. Wahyuddin, Penerj.) Bandung: Pustaka.

Al-Fatih, K. (2017). Kuttab Al-Fatih Official Website: Frequently Asked Question. Retrieved Januari 22, 2018, from Al-Fatih Pilar Peradaban: Gemilang di Usia Belia: http://www.kuttabalfatih.com/faq/

Ali, S. (2014, November 9). Pemimpin: Antara Kepemimpinan dan Keshalehan. Retrieved Januari 20, 2018, from Madrasah Nubuwwah: http://madrasahnubuwwah.blogspot.co.id/2014/11/antara-kepemimpinandan-keshalehan.html

Al-Mubarakfuri, S. (2016). Ar-Rahiq Al-Makhtum: Sirah Nabawiyah. (F. K. Anam, Trans.) Jakarta: Qisthi Press.

Al-Qur'an. (2015). Al-Qur'an Terjemahan Departemen Agama RI. Bandung: CV Darus Sunnah.

Al-Sijistani, A. A. A. (2013). Ensiklopedia Hadits 5: Sunan Abu Dawud, Terj. Muhammad Ghazali dkk, Cet I. Jakarta: Almahira.

Antonio, M. S. (2009). Muhammad Saw: The Super Leader Super Manager. Jakarta: Tazkia Publishing.

Asadullah, M., \& Chaudhury, N. (2010). Religious Schools, Social Values, and Economic Attitudes: Evidence from Bangladesh. World Development, 38(2), 205-217. DOI: https://doi.org/10.1016/j.worlddev.2009.10.014.

Asari, H. (2013). Menyingkap Zaman Keemasan Islam: Kajian atas Lembagalembaga Pendidikan. Bandung: Citapustaka Media. 
At-Thayyar, M. (2010). Interaksi Dengan al-Qur'an di Bulan Ramadhan. (E. H. Ziyad, Penyunt., \& S. A. Difa, Penerj.) Jakarta: islamhouse.com.

Baharun, H. (2016). Metodologi Studi Islam: Percikan Pemikiran Tokoh dalam Membumikan Agama. Yogyakarta: Ar-Ruzz Media.

Boulakia, J. (1971). Ibne Khaldun-A Fourteenth-Century Economist. Journal of Political Economy, 79(5), 1105-1118. DOI: https://doi.org/10.1086/259818.

Browne, J. (1977). History Repeats Itself. Journal of Further and Higher Education, 1(2), 74-79. DOI: https://doi.org/10.1080/0309877770010210.

Dahlan, Z. (2018). Sejarah Pendidikan Islam: Signifikansi Jejak Pendidikan Islam Bagi Pengembangan Pendidikan Islam Masa Kini dan Masa Depan. Medan: Widya Puspita.

Dangor, S. (2005). Islamization of Diciplines: Towards an indigenous educational system. Journal of Educational Philosophy and Theory, 519-531. DOI: https://doi.org/10.1111/j.1469-5812.2005.00138.x.

Dariah, A., Salleh, M., \& Shafiai, H. (2016). A New Approach for Sustainable Development Goals in Islamic Perspective. Procedia - Social and Behavioral Sciences, 159-166 DOI: https://doi.org/10.1016/j.sbspro.2016.05.001.

Dwiantika, N., \& Rosalina, D. (2014, November 06). BI Ingin Pangsa Perbankan Syariah tembus 30\%. Retrieved 12 20, 2019, from Kontan.co.id: https://keuangan.kontan.co.id/news/bi-ingin-pangsa-pasar-perbankansyariah-tembus-30

Fathurrahman, A. (2010, Oktober 11). Strategi Rasulullah Membangun Perekonomian Madinah. Retrieved January 15, 2017, from Bakumpai Raya: https://ayieffathurrahman.wordpress.com/2010/10/11/ramadhanmomentum-untuk-mengurangi-tingkat-kemiskinan/

Fauzi, I. (2012). Manajemen Pendidikan ala Rasulullah. Yogyakarta: Ar-Ruzz Media.

Fridiyanto, A. (2018). Kaum Intelektual dalam Catatan Kaki Kekuasaan. Yogyakarta: Gre Publishing.

Greene, K., \& Joon, Y. B. (2004). Religiosity, Economics and Life Satisfaction. Journal Review of Social Economy, 62(2), 245-261 DOI: https://doi.org/10.1080/00346760410001684460.

Hajaj, N.-H. (2008). Shahih Muslim. Mesir: Maktabah 'Ibad Ar-Rahman.

Hanafi. (2017). Urgensi Pendidikan Adab dalam Islam. Saintifika Islamica: Jurnal Kajian Keislaman, 59-78.

Hanbal, A. (1995). Musnad Ahmad. Kairo: Dar al-Hadits.

Hanif, N., \& Arshed, N. (2016). Relationship between School Education and Economic Growth: SAARC Countries. International Journal of Economics and Financial Issues, 6(1), 294-300. Retrieved from https://dergipark.org.tr/en/pub/ijefi/issue/32008/353685.

Hanifullah. (2012). Membangun Sistem Ekonomi Umat Berbasis Syariah. Episteme, 7(2), 268-292. DOI: http://10.21274/epis.2012.7.2.267-292.

Hariyanto, M. (2016). Keluargaku : "Al-Madrasatul Ula". Repository Universitas Muhammadiyah Yogyakarta, 1-2. 
Hidayah, N., Lowe, A., \& Woods, M. (2019). Accounting and Pseudo Spirituality in Islamic Financial Institutions. Elsevier: Critical Perspectives on Accounting, 61, 22-37. DOI: https://doi.org/10.1016/j.cpa.2018.09.002.

Hitti, P. (1974). History of The Arabs. London: The Macmillan Press.

Hitti, P. (2001). Sejarah Ringkas Dunia Arab, terj. Usuluddin Hutagalung dan ODP Sihombing. Yogyakarta: Pustaka Iqra'.

Hossain, B. (2019). Islamization of Monetary Policy of 27 OIC Muslim Countries in Asia: The Successes, The Barriers and The Future Directions. Global Review of Islamic Economics and Business, 7(2), 91-104. DOI: https://doi.org/10.14421/grieb.2019.072-04.

Ibnu Majah, M. Q. S. (2018). Sunan Ibnu Majah, cet II. Riyadh: Daarul Ma'arif Linnasyri Wattaauzi'.

IFSB. (2016). Islamic Financial Service Industry Stability Report. Kuala Lumpur: Retrieved from Malaysia.

Kotásková, S. K., Procházka, P., Smutka, L., Maitah, M., Kuzmenko, E., Kopecká, M., et al. (2018). The Impact of Education on Economic Growth: The Case of India. Journal of Acta Universitatis Agriculturae et Silviculturae Mendelianae, 66(1), 253-262. https://doi.org/10.11118/actaun201866010253.

Lapidus, I. (2000). Sejarah Sosial Umat Islam. Jakarta: Raja Grafindo.

Mahayudin, Y., \& Halimi, A. J. (1997). Sejarah Islam. Kuala Lumpur: Fajar Bakti SDN.BHD.

Mahyudi, M. (2015). 'True Man': The True Economic Man for Islamic Economics. Global Journal Al-Thaqafah, 5(2), 63-72. DOI: https://doi.org/10.7187/GJAT912015.05.02

Mahyudi, M. (2016). Rethinking the Concept of Economic Man and Its Relevance to the Future of Islamic Economics. Journal of Intellectual Discourse, 24(1), 111-132. Retrieved from https://journals.iium.edu.my/intdiscourse/index.php/islam/article/view/713

Mahyudi, M., \& Aziz, E. (2018). Method and Substance of Islamic Economics Revisited. Journal of King Abdulaziz University: Islamic Economics, 31(2), 33-50. Available at SSRN: https://ssrn.com/abstract=3465449.

Multazam, A. (2013, Desember 6). Pendekatan Sejarah dalam Memahami Agama. Retrieved Januari 5, 2018, from Islamic Centre: https://multazameinstein.blogspot.co.id/2013/12/pendekatan-sejarah-dalam-memahamiagama.html

Nienhaus, V. (2013). Method and Substance of Islamic Economics: Moving Where? Journal of King Abdulaziz University: Islamic Economics, 26(1), 169-202. DOI: http://doi.org/10.4197/Islec.26-1.9

Novianti, I. (2015). Reorientasi Model Pendidikan Islam Klasik di Indonesia (Studi Terhadap Kuttab Al-Fatih). Purwokerto: Lembaga Penelitian dan Pengabdian Masyarakat IAIN Purwokerto.

Nurcholis, A. (2014). Upaya Islamisasi Ilmu Ekonomi sebagai Solusi Menuju Masyarakat yang Berkeadilan. Jurnal Al-Maslahah, 9(2), 1-18. DOI: https://doi.org/10.24260/almaslahah.v9i2.683. 
Nurhayati, \& Syahrizal. (2015). Urgensi dan Peran Ibu sebagai Madrasah al-Ula dalam Pendidikan Anak. Itqan, Vol.VI, No.2, 153-166. Retrieved from https://ejurnal.iainlhokseumawe.ac.id/index.php/itqan/article/view/49.

Permani, R. (2009). The Economics of Islamic Education: Evidence from Indonesia. Australia: A thesis submitted to the School of Economics of Adelaide University in fulfillment of the requirements for the degree of Doctor of Philosophy.

Rahman, T. A., Yusuf, W. W., Rashid, Z. M., \& Amir, A. N. (2015). Al-Faruqi's Fundamental Ideas and Philosophy of Education. Dinamika Ilmu, Vol.15 No.2, 235-248. DOI: http://dx.doi.org/10.21093/di.v15i2.146.

Safiq, M. (1995). Islamization of Knowledge, Philosophy, and Methodology and Analysis of The Views and Ideas of Ismail Raji al Faruqi, Husein Nasr, and Fazlur Rahman. Dalam A. Soleh, Wacana Baru Filsafat Islam (hal. 239). Yogyakarta: Pustaka Pelajar.

Sardar, Z. (1998). Jihad Intelektual, Merumuskan parameter-parameter Sains Islam. (A. Priyono, Penyunt.) Bandung: Risalah Gusti.

Scheepers, P., Grotenhuis, M., \& Slik, F. (2002). Education, Religiosity and Moral Attitudes: Explaining Cross-National Effect Differences. Journal of Sociology of Religion, 63(2), 157-176. DOI: https://doi.org/10.2307/3712563.

Septyaningsih, I., \& Zuraya, N. (2018, Desember 08). Penyebab Perkembangan Bank Syariah di Indonesia Lambat. Retrieved 12 20, 2019, from Republika.co.id: $\quad$ https://www.republika.co.id/berita/ekonomi/syariahekonomi/18/12/08/pjdd1q383-penyebab-perkembangan-bank-syariah-diindonesia-lambat

Syalabi, A. (1973). Sejarah Peradaban Islam. Jakarta: Bulan Bintang.

Syamsuri, \& Harahap, S. A. (2019, Januari). Analysis of Human Resources Development in The Foundation Institute of National Zakat Al-Falah Social Fund (YDSF) Surabaya From Islamic Economic Perspective. al-Uqud: Jurnal of Islamic Economics, 3(1), 34-53. DOI: http://dx.doi.org/10.26740/aluqud.v3n1.p34-53.

Tahir, S. (2017). Islamic Economics and Prospects for Theoretical and Empirical Research. Journal King Abdulaziz University: Islamic Economics, 30(1), 320. Available at SSRN: https://ssrn.com/abstract=3057331.

Taufik, M., \& Yasir, M. (2017). Mengkritisi Konsep Islamisasi Ilmu Ismail Raji Al-Faruqi: Telaah Pemikiran Ziauddin Sardar. Jurnal Ushuluddin Vol.25 No.2, 109-123. DOI: https://dx.doi.org/10.24014/jush.v25i2.3830

Wangsadanureja, M. (2018). Urgensi Manajemen Pendidikan Pesantren dalam Keluarga. Islamic Management: Jurnal Manajemen Pendidikan Islam, I(2), 257-270. DOI: https://dx.doi.org/10.30868/im.v1i2.279

Yatim, B. (2011). Sejarah Peradaban Islam. Jakarta: Raja Grafindo Perkasa.

Zarqa, M. A. (2003). Islamization of Economics: The Concept and Methodology. Journal of King Abdulaziz University: Islamic Economics, 16(1), 3-42. Available at SSRN: https://ssrn.com/abstract=3073793.

Zen, E. S., \& Khairiyah, N. (2014). Pendidikan Agama Islam dan Budi Pekerti. (Y. Hasan, Penyunt.) Jakarta: Kementerian Pendidikan dan Kebudayaan. 